\title{
Human Rights and Leadership in Africa: The Nigerian Connection in Buhari Administration
}

\author{
Paul Okwuchukwu Azuakor \\ http://dx.doi./org/10.4314/ujah.v20i3.9
}

\begin{abstract}
Human Rights are moral norms or principles which describe certain standards of human behaviour. These rights are regarded under municipal and international law as natural and legal entitlements of all individuals and are thus protected. Such rights include right to life, right to social security, right to freedom of thought, right to freedom of speech, right to religious freedom, right to private property, right to democracy, right to gainful employment, etc. The United Nations Universal Declaration of Human Rights lists 30 of such rights. The Nigerian constitution also covers human rights. But leadership in Africa has many times been faced with issues of abuse of human rights; Nigeria not being an exception. This paper is interested in investigating the extent to which these rights have been respected or abused in Africa, but with special focus on Nigeria, and the Buhari administration as the special interest. The theoretical framework is the historical and the tools of enquiry are the critical, the analytical and expository. Recommendations include: evolution of solid political ideology of leadership couched on service for Africa by Africans, demolition of the cankerworm of tribalism in Africa/Nigeria, the elimination of religious fanaticism, education in ideal humanity from earliest childhood, etc.
\end{abstract}

Keywords: Human Rights, Africa, Nigeria, leadership, Buhari administration 


\section{Introduction}

The description of what human rights are by Ofoegbu is fascinating. For Ofoegbu (2013) "Human Rights are ontological, inherent and intrinsic to all human beings in as much as they are human, irrespective of nationality, sex, ethnicity, origin, colour or any other status" (p. 60). A functional democracy couched on the rule of law is essential for the protection of these rights. Human rights being ontological and inherent to the human person mean they belong inalienably to the human person. Theoretical and conceptual development of the idea has evolved through the ages right from antiquity till date. The universal declaration of these rights by the United Nations on $10^{\text {th }}$ December, 1948 at the aftermaths of World War II, considered to be the most devastating war mankind has faced until now, is however epochal. Considering the colonization of many nations by stronger nations and the events of slavery, especially the Trans-Atlantic Slave Trade, the perception that every human person, by virtue of being human is entitled to certain rights regarded as human rights is relatively new. It is in this context that Ofoegbu (2013) states that, "it took the catalyst of World War II to propel human rights onto the global stage and into the global conscience" (p. 63).

Africa and Nigeria being the conquered people by the European invaders suffered and have continued to suffer human rights abuses. Our own brothers and sister who now rule us are sometimes influenced to abuse their fellow countrymen. But it is the intention of this paper to sting African nay Nigerian leaders to consciousness of the need to respect themselves and the people they govern so that we can collectively build Nigeria and African nations, have our respect for our culture and achievements and thus be respected by the peoples of the world. 


\section{Clarification of Concepts}

In order to facilitate analysis, comprehension and examination of the crux of the issues posited and discussed in this paper and to better situate our context, the clarification of the following concepts is crucial: human rights, Nigeria, Africa, leadership, and Buhari administration.

\section{Human Rights}

Human rights are principles, norms for a general attitude and determination of reality for both an individual and the larger society. They deal with the claims, needs and demands of human beings as human beings which must be respected and guaranteed as contributory to self-realization. This can be seen from many dimensions. For Okechukwu (1990),

From a moral point of view, human rights are rights which human beings have from the very fact that they are human. They have these rights irrespective of their social status, moral merits, religious beliefs, class membership, etc; and these rights exist prior to the establishment of states. (p. 39).

The United Nations in its December 10 Universal Declaration of Human Rights, listed the civil and political liberties (Articles 1-21) and the social, economic and cultural rights (Articles 22-28) as all human rights. The Federal Republic of Nigeria (1999) came up with a constitution. Chapter four of that constitution (sections 3343) lists the following as fundamental human rights in agreement with international conventions: right to life, right to dignity of human person, right to personal liberty, right to fair hearing, right to private and family life, right to freedom of thought, conscience and religion, right to freedom of expression and the press, right to 
peaceful assembly and association, right to freedom of movement, right to freedom from discrimination, and right to acquire and own immovable property anywhere in Nigeria.

\section{Africa}

Africa is the second largest continent of the world both by population and land mass after Asia, with an area of about 11,700,000 square miles (30,420,000 km2). And for Jarrett (1974), it is about three times the size of Europe and yet it has a much shorter coastline because its coasts are remarkably smooth in general. The equator cuts almost exactly midway across Africa; Cape Blanc, lies 37degrees north of the equator as the most northerly point, and Cape Agulhas lies 35degrees south as the most southerly point. About two-thirds of the total area of Africa lies between the Tropics of Cancer and Capricorn (some refer to places lying within here as "inter-tropical"). Rather more than half of Africa lies in the northern hemisphere because of the extensive westward bulge of the Barbary States- West Africa (including Nigeria) and the Sahara Desert- whereas the southern part of Africa tapers gradually towards the Cape Province. A straight line from north to south of Africa, at its highest distance is about 5000 miles $(8000 \mathrm{~km})$, and from the east to west is about 4500 miles $(7200 \mathrm{~km})$. Cape Verde is the most westerly point of the continent, Cape Ras Hafan being the most easterly. Madagascar, the African island nation to the south is larger than France in land mass. Africa has 54 recognized countries (2 disputed- Western Sahara and Somaliland). Although most, if not all, countries in Africa practice one form of democracy or the other, Kweifio-Okai and Holder (2016) hold that "A club of authoritarian leaders have maintained an iron grip on power in parts of Africa, either by amending laws to extend their terms of office, hosting rubber-stamp elections or 
repressing opposition and civil society". This is a pointer to human rights abuse.

\section{Nigeria}

Nigeria is a country operating the federal system of government after the American model. But Nigeria came into existence with the 1914 amalgamation of what was then the Northern and Southern Protectorates under the British colonial administration with Sir Lord Lugard as the Governor General. Nigeria gained political independence from Britain on October 1, 1960 and was running a parliamentary system of government after the British model. She became a republic in 1963. For Wikipedia (2019), "By the time that Nigeria had declared itself a republic and replaced the post of Governor-General with the post of President, a national bicameral parliament was established and the country was considered a federation of the [then] three regions" (p. 1). Today, Nigeria is made up of 36 states and a federal capital territory, Abuja. The population is considered to be over 180 million. Nigeria has land borders with Benin Republic to the west, Chad and Cameroon to the east, and Niger to the north. Its costal borders are the Gulf of Guinea (Atlantic Ocean) in the south and Lake Chad in the northeast. There are over 250 ethnic groups in Nigeria, the three major ones being the Yoruba, the Hausa/Fulani and the Igbo. The major religions are Christianity, Islam and African Traditional Religion. The ethnic and religious realities in Nigeria have often been pivotal in Nigeria's problems including those of human rights nature.

\section{Leadership}

This means a lot of things to a lot of people. But here we mean political leadership. Leadership according to Obingene and Okeke 
(2004) "is concerned with the initiation, organization and direction of the actions of the members of a group in a specific situation towards the achievement of the objectives of the group" (p. 63). The group here is Africa and more specifically, Nigeria. The goal in question here is human rights within the nexus of African/Nigerian larger goals.

\section{Buhari Administration}

By Buhari administration, this paper focuses on the democratic leadership under President Muhammadu Buhari, the Nigerian President, from May $29^{\text {th }} 2015$ till date. It does not concern itself with his spell at leadership through a coup d'état of December $31^{\text {st }}$ 1983 and which was toppled by the General Ibrahim Badamosi Babangida administration that started in 1985.

\section{Theoretical Framework}

We have adopted in this paper the historical theory, which is a flexible framework that uses the examination and analysis of knowledge from history, that is, the knowledge of the things that happened in the past, how such knowledge was assembled, articulated and presented, and how such knowledge is applicable to the events of the present and how it can be used to influence the future. It is perceived and used here as a fitting framework for studying the emergence of the use or abuse of human rights by leaders in Africa in the past, how through history human interventions have accelerated or abetted abuse of human rights in Africa (and Nigeria in particular), what the current state is and what Africans are doing to secure a better human rights record in the continent for the future. 


\section{Human Rights Issues in Africa}

Human rights situation in Africa is far from commendable in general. For Magnarella (2000) over five decades since the United Nations declaration of universal human rights and decades after the Organisation of African Unity (OAU) adopted its own Charter on Human and Peoples' Rights, the human rights situation in Africa remains decidedly bleak. He further states that, in fact, the attainment of genuine rights in Africa would seem a crucial project for Africa in the $21^{\text {st }}$ Century. In the 1990s many African countries like Sierra Leone, Guinea Bissau, Congo, Angola, Democratic Republic of Congo, Somalia, Burundi, Rwanda, Ethiopia and Eritrea were ravaged by war with the accompanying human rights abuses. In fact writing about an incident of June 1999, Magnarella (2000) notes:

a report by the Coalition to Stop the Use of Child Soldiers estimated that more than 120,000 children from ages seven to seventeen were being exploited as soldiers across Africa. Some of these children voluntarily joined government or revolutionary armed forces, but tens of thousands of them were forced to become soldiers at gunpoint (p. 17).

These abuses have not been completely addressed in those and other African countries today. Magnarella (2000) holds that an OAU report attributed the poor human rights record in Africa to mainly racism, poverty, post-colonialism, religious intolerance, disease, debt, internal conflicts, the monopoly of power, bad management, corruption, lack of judicial and press autonomy, and border conflicts. It is very clear that majority if not all of these issues hinge on leadership. Good leadership will practically eliminate them all. More than $70 \%$ of the continent's over 700 million people live below the poverty level; a situation caused by 
bad leadership by African governments as Africa is a continent so richly endowed with human and material resources- more endowed by some other continents that are having a good life due to good leadership. And poverty is a very welcome ambient for exploitation and abuse of rights. Magnarella further posits that the African nations cannot be construed in the same way as European nations which are blocks of various peoples who evolved over the years as distinct peoples with cultural, tribal, linguistic and political identity. But in the case of African nations, the colonialists never took into consideration the political and social groupings that were in existence before their entrance, they just fused peoples with no cultural, social or political affiliations and in many cases divided those who had these for their own political and economic interest. This has led to formation of "independent" African states made up of peoples with no binding force for national interest, but are rather drawn towards their tribal origins. This has occasioned African leaders pandering to the interests of their particular tribes and selves while abusing the human rights of peoples outside their own tribes. Thus Magnarella (2000) writes:

The bias of the UN and existing states against autonomy or secessionist movements by cultural minorities seeking selfdetermination and political independence from dominant ethnic power-holders could very well prove detrimental to both the stability of states and the human rights process. (p. 19).

This is one major cause of crises and gargantuan abuse of human rights in many African nations, including Nigeria - the Boko Haram, Movement for the Actualization of the Sovereign State of Biafra (MASSOB), Indigenous People of Biafra (IPOB), the Movement for the Emancipation of the Niger Delta (MEND), 
Niger Delta Avengers (NDA) in Nigeria and the human rights violations occasioned by some of these groups as well as those produced from the side of the government forces are clear examples of the negative effects of the colonial administrators' penchant for lopping up African peoples to form nations irrespective of their cultural, religious, ethnic, language, social and cultural dissimilarities. This high-handedness on the part of the colonialists was occasioned, among other things, by the racist bias of the inferiority of anything African- Africans who were regarded at some points as sub-human, incapable of abstract reasoning and even lacking a soul. African nations are still grappling with the devastating effects of these in their various governments.

African leaders who had adopted the UN charter of human rights still had to create an African charter of human rights on October $21^{\text {st }}, 1986$. By then Europe and the Americas had already established theirs. And citing Okoth-Ogendo (1993), Magnarella (2000) posits that African leaders felt the need to do this so as to put in place a set of human rights based on African norms and principles rather than just copying and practicing human rights based on American and European norms and principles. And for Magnarella (2000), "The African Charter both resembles and departs from the other regional conventions" (p. 21). The Charter contains such rights as rights to equal protection of the law, to education, to due process, to life, to own property, to mental and physical health, etc. The Charter, however, differs from other regional charters in demanding obligations from the individual to the state. This has drawn severe criticisms from critics, as they feel politicians might exploit the people when such obligations clash with state obligations. But defenders like Mutua (1995), according to Magnarella, argue that it is a way of Africans trying to defend Africa, given its history of domination from foreign nations, from 
external exploitation. For example, when it talks about individuals having obligation of using their intellect to serve the state, it is a kind of safeguard against the massive brain-drain that Africa has been suffering for long.

Soon following the African Charter of human rights was the African Human Rights Commission which was established in 1987. But as human rights abuses continued to fester in Africa, African leaders saw the need for African Court of Human and Peoples' Rights. This was established in 2004. For Fleshman (2004), "The court adds an enforcement arm to existing human rights institutions on a continent known more for the impunity of those who govern than the strict defence of the rights and liberties of citizens" (p. 1). Human rights violations by the colonial masters was a potent tool by African freedom fighters to wrestle power from the colonialists, but having obtained independence, and then the emergence of the Cold War, authoritarian regimes ensued in Africa which sought security from foreign alliances having hijacked powers and trampled the ballot boxes. This then made them feel at liberty to violate the human rights of their citizens. And for Fleshman (2004), "The wave of democratization that swept Africa in the 1990s, the emergence of a vigorous civil society and greater donor pressure combined to impel important changes in official thinking on human rights" (p. 2). Thus for Igue (2010), before Africa can achieve genuine development, her new leaders have to, among other things, promote democracy and human rights and implement new conditions for peace and freedom. For Human Rights Watch (2019), new leadership in major Southern Africa countries has reinvigorated hope for increased respect for human rights although the leaders in the region have not lived up to this expectation in 2018. In South Africa, human rights record did not change irrespective of a new 
leader, Matamela Cyril Ramaphosa, taking over the rein of government from the former president, Jacob Zuma, in February. In Zimbabwe, there was post-election violence and military crackdown on opponents after relatively peaceful national elections in July, the first in 30 years in which Robert Mugabe was not on the ballot. President João Lourenço's Angola presented a mixed picture, for though the political and civil rights environment became less restrictive and there were apparent non-interference with court operations, yet abuses continued with impunity. And other Southern African countries with checkered human rights records in 2018 included Mozambique and Eswatini (former Swaziland).

\section{Nigeria and Matters of Human Rights}

For Mbanefo and Iloegbunam (2016), the emergence of handling of fundamental human rights and freedoms in the Nigerian political sphere is traceable to a number of international documents: United Nations Declaration of Human Rights (1948), American Declaration of the Rights and Duties of Men (1948), European Convention on Human Rights (1950), British Government Convention for the Protection of Minorities (1957) and the African Charter on Human and Peoples Rights (1981). The various governments in Nigeria have been aware of the requirements of human rights in dealing with the Nigerian people. It is even contained in the constitution of the land. In 2006, the Federal Government of Nigeria came out with a document on the national action plan for the promotion and protection of human rights in Nigeria. The contents of that document are: a brief history of human rights in Nigeria, the concept of the National Action Plan (NAP), developing Nigeria's NAP, organizing structures and consultative process, framework for discussion of rights contained 
in the draft NAP, framework for discussion of each right, civil and political rights, economic, social and cultural rights, right to development, peace and a protected environment, and then rights of women, children and young persons. This document holds that the idea of human rights has always been among the Nigerian people even before the onset of colonial rule, but that the entrenchment of human rights in the modern era by way of a written document could be traced to the 1960 Independence Constitution and the ones that followed. But, despite the entrenchment of the rights and liberties of the people in the constitution, the Nigerian people have been unfortunate to have the violation of these by various military juntas. For this document, before the dawn of the present democracy in Nigeria in 1999, successive military regimes systematically violated, with impunity, the rights of Nigerians. This violation reached its high point between November 1994 and June 1998 during the Abacha regime. For Federal Republic of Nigeria (2006), "The abysmal situation of human rights under this regime resulted in Nigeria becoming a pariah state at the international arena and the country was put on the agenda of the United Nations Commission on Human Rights for five consecutive years" (p. 3). It took the actions of human rights civil society groups and professional bodies who engaged the military in the struggle for a better Nigerian society governed by a constitution, the rule of law, social justice and respect for human rights to eventually bring about the return to democracy with a new Constitution for the Federal Republic of Nigeria in 1999. This constitution made adequate provisions for the respect of human rights.

The only problem is the adherence to the dictates of human rights for Nigerian citizens in practice. The fundamental human rights of Nigerian people are very explicit in the 1999 constitution; 
the only problem is that the various governments have in varying degrees not kept to these dictates of the constitution on human rights of Nigerians. For Ofoegbu (2013), "Almost all the institutions of government saddled to promote and protect human rights and dignity have relatively failed if not totally" (p. 69). Furthermore, Ofoegu points out that the most significant human rights abuses in Nigeria are extra-judicial killings, arbitrary arrests and excessive use of force by security forces, prolonged pre-trial detentions, executive lawlessness, judicial corruption and executive influence on the judiciary. For the Catholic Bishops' Conference of Nigeria, CBCN, (2010), "the institutions that ought to protect our democracy - the executive, the legislature, the judiciary, and the press are not doing enough for the people, and are not yet always at the service of our God-given freedom" ( $p$. 26). Various freedoms are part of fundamental human rights. According to Hussaini and Tsaku (2016), "In a democratic Nigeria, all these rights are being violated directly or indirectly" (p. 13). And according to Ofoegbu (2013), human rights are not respected in Nigeria's democracy. For Ofoegbu, "Extra-judicial killing, unlawful detention, and other series of human rights abuses are still prevalent in Nigeria (sic) democracy" (p. 60).

As for Hussaini and Tsaku (2016), "people's lives in Nigeria are of little importance to the people they elect to represent them. Yet, when it is time for election, the political elites still fall back to these voiceless people canvassing for votes" (p. 5). They presented the contrary to the case in some other climes, like a minister of education resigning in South Korea because some students had drowned when a plane crashed despite the fault lying with the pilot; and in China, where government had to immediately find a safe haven for surviving victims of a fertilizer plant explosion in August 2015, whereas when Chibok school girls were 
abducted by the deadly Boko Haram terrorists in Nigeria, the minister in-charge of that ministry dismissed it as one of those happenstances in life.

Essien (2016) observed that Nigeria is blessed with men and women who have struggled through the years fighting for the ensuring of justice, fair-play, equity, and the entrenchment of an egalitarian society where the fundamental rights of all citizens but especially the downtrodden are respected. But according to him, they have as a result of this suffered greatly in the hands of government through incarceration, dehumanization and other forms of abuses.

\section{Human Rights Issues under Buhari Administration (2015- Date)}

Discussing matters of human rights under the Buhari administration, the United States Department of State, Bureau of Democracy, Human Rights and Labor (2018) states:

Human rights issues included unlawful and arbitrary killings by both government and nonstate actors; forced disappearances by both government and nonstate actors; torture by both government and nonstate actors and prolonged arbitrary detention in life-threatening conditions particularly in government detention facilities; harsh and life threatening prison conditions including civilian detentions in military facilities, often based on flimsy or no evidence; infringement on citizens' privacy rights; criminal libel; substantial interference with the rights of peaceful assembly and freedom of association (p. 1).

Continuing, the United States Department of State (2018) notes that there were many reports of Buhari government and its agents 
committing arbitrary and unlawful killings. The army, police and other security services used lethal weapons and excessive force to disperse protesters and apprehend criminals and suspects while committing extrajudicial killings. And the government generally did not hold these security force personnel accountable for their crimes against human life. It also notes that state and federal investigating panels into such human rights abuse cases generally did not make their findings public. Prof. Yemi Osinbajo, as the acting President, in August 2017, set up a civilian-led presidential investigative panel to see that the armed forces adhered to human rights obligations and rules of engagement, the panel submitted its report in February of 2018, but as at November 2018 nothing had been mentioned about it.

The State Security Service (SSS) under Buhari, according to the United States Department of State (2019) held Jones Abiri, accused to be a member of a Niger Delta militant group, in response to a critical coverage done in the July 2016 edition of Weekly Source. He was blindfolded (for most of the time) and held in detention for more than two years without access to medical attention, without being formally charged, allowed bail, family visit or counsel. It took the intervention of the Committee to Protect Journalists (CPJ) and public outcry for him to be eventually arraigned and released on bail. There were other forms of human rights abuse by non-government agents in the forms of abductions, piracy and related crimes by such groups as the Boko Haram, ISISWA, Niger Delta militants and the likes.

But for the United States Department (2018), "In December 2017, the president signed the Anti-Torture Act, which defines and specifically criminalizes torture" (p. 5). It stipulates the attending punishments for all law enforcements officials who may be found guilty of the crime. It was also reported that the prisons were 
overcrowded. As at July 2018, the Nigerian prison services had the capacity to hold 50, 153 inmates but were actually holding 73,631, $68 \%$ of them being awaiting trial cases; 1,475 of them all were females, and females were in most cases held in the same prisons with males, and juveniles with adults.

Ibekwe (2019) states that the US Department of State in its "Country Reports on Human Rights Practices for 2017" noted that the Buhari administration was culpable of not investigating allegations of abuse of human rights especially those that concerned top officials of government and members of the armed forces, nor did it prosecute those indicted for being the chief impediments to the fight against human rights violations. The report further observed that at all levels of government, impunity remained widespread. Major allegations of abuse of rights by security operatives were not properly investigated and prosecuted nor were police and military extortions or other abuse of power properly investigated and prosecuted. Again, the government did not make the police, military or other security forces to be accountable for excessive or deadly use of force or for even the deaths of persons in custody. Furthermore, as of November 2017, the Buhari administration had not adequately investigated or made the police or military accountable for the extrajudicial killings of IPOB movement supporters in 2016 and Amnesty International (AI) had reported that at least 150 IPOB members or supporters were killed and others arbitrarily arrested in their hundreds from August 2015-August 2016. The Nigerian Army (NA) reportedly investigated and treated the matter as mere part of a broader Board of Enquiry (BOI), but its full report was not published. No police or military was disciplined or prosecuted. And then, as of November 2017, there were no further reports, investigation or holding individuals accountable for 2015 killings and mass burial 
of members of Shia Islamic Movement of Nigeria (IMN) group, including other civilians by the NA in Zaria, Kaduna State. The federal government had indicated it would wait for the results of a Kaduna State judicial commission enquiry before venturing into further investigations or holding culprits to account; by July of 2016 a nonbinding report was made public by the commission which found the NA guilty of using "excessive and disproportionate" force during that 2015 altercations in which 348 members of IMA and a soldier died. The report also showed that despite social media outcry on the human rights atrocities of the police Special Anti-Robbery Squad (SARS), and the civilian Joint Task Force (JTF) in north east Nigeria, the Buhari government had not taken any recognizable action to address the ugly situation.

Campbell (2019) posted a blog to the effect that at the inauguration of Buhari's second tenure, Amnesty International issued a 20-page indictment report of his administration in the area of human rights violations by state and non-state agencies, but especially the security services. It called the Buhari administration to address the perennial human rights abuses in Nigeria by taking or recommending specific decisive actions.

Adebayo (2018) wrote that at the inception of Buhari's administration in 2015 he swore the oath of office wherein he promised on oath to respect and abide by the fundamental objectives and directive principles of the Constitution of the land and that he would do right to all and sundry under the law without fear or favour. Furthermore, in the famed Chatham House address, he claimed to be a converted democrat. But for Adebayo, "A number of events that have taken place under the president's watch in his first three years show that his government has violated fundamental human rights, entrenched in the country's constitution, and condoned such violations (p. 1). Such events 
according to Adebayo include: the Zaria Massacre of 2015, the continued detention of El-Zakzaky (continued detention of Sambo Dasuki whom at least 5 courts of competent jurisdiction had ordered his release), harassment of journalists, indictment by the United States, and indictment by Amnesty International.

Nigerians have watched in dismay as Fulani herdsmen under the Buhari administration have ransacked whole villages killing, maiming, raping women, destroying people's farms, burning their homes and, in some places, taking over their towns. The government by its inaction and body language has not done anything to stop the rampage such that many have accused Buhari of collusion with his kins to perpetrate such crimes against human rights in Nigeria. In Benue hundreds of people were killed by herdsmen, others were slain in the dead of the night as they slept in their homes by herdsmen at Ukpabi-Nimbo, Enugu State on April $25^{\text {th }}$, 2016. For Azuakor and Onebunne (2016), "The recent killings in Nimbo by the Fulani herdsmen is an indication of what they go about doing around the country. They invaded, armed and left several people dead" (p. 96). Brisibe (2018) reporting for Niger Delta Voice in Vanguard Newspaper wrote on how the women of Ewu-Urhobo community of Ughelli South LGA, Delta State had to go on demonstration to protest herdsmen's activities, who uprooted their cassava and fed them to their cattle, maimed or killed anyone who dared to resist. They protested that even the state government had not been able to do anything to help then even when such crimes had continued in their community and neighbouring towns for long. For the women, according to Brisibe, "Cattlemen claim all lands belong to President Buhari" (p. 28) and for that reason none of them had right to prevent them invading their farms. Thus Atupulazi (2016) observed that in recent times, some Nigerians have been parading themselves as untouchables, which perception 
had goaded them into committing atrocious crimes, which have sadly not been dealt by government with the severity they demanded.

For Babalola (2019), "the mishandling of Nigeria's malignant herdsmen crisis exemplifies the duplicitous nature of the present administration" (p.1). It is sad that rather than the administration bringing herdsmen who had committed atrocities through the length and breadth of Nigeria to book, the Buhari administration proposed to settle them in every state by seizing people's lands and handing them over to the Fulanis in what the government termed RUGA (Rural Grazing Area) project. Nigerians strongly resisted this, which led to its suspension and the proposal of yet another unacceptable scheme skewed in favour of an "elite" set of Nigerians against the "second class" citizens- the National Livestock Transformation Programme. Many eminent Nigerians protested against RUGA including church leaders, the former President, Olusegun Obasanjo, Wole Soyinka, and the Ooni of Ife, Oba Adeyeye Ogunwusi. Reporting for the Nation and referring to Soyinka and the Ooni of Ife, Mordi (2019) notes: "the eminent citizens called on Nigerians across the states to defend the sanctity of their ancestral lands, because such birthright has never been annulled, "not even under colonial occupation" (p. 6). For goodness sake livestock business is personal business and any state could as well choose to venture into it, but it should never be a policy of federal government which includes grabbing certain people's lands to settle certain "privileged" Nigerians (or even foreigners, as some claim that the terrorist Fulanis are not Nigerians) just because the administration has Fulani interest. 


\section{Evaluation}

It is commendable that African and Nigerian leaders have from the time of the colonial masters fought for the respect of human rights in their various domains. Such fighting and struggles ultimately led to the attainment of independence from the colonial masters giving Nigerians and Africans the human rights they deserved namely to be free to have their lands, express themselves and have association without fear of domination. It is equally commendable that following international conventions of human rights like the UN Charter of $10^{\text {th }}$ December 1948, Africa also evolved her own Charter of human rights in 1981. It is as well to be applauded that the constitutions of many African countries have enshrined in them the respect of human rights in all their ramifications, example being the 1999 Constitution of the Federal Republic of Nigeria.

It is also a thing of joy that regional governments in Africa like the Southern African one, discussed in this paper are making serious efforts to ensure that human rights are respected in the regions. In Nigeria, specifically, the Federal Government came out in 2006 with a document on the National Action Plan for the promotion and protection of human rights in Nigeria. These are all commendable. Human rights groups and the press in Africa and Nigeria have also been known to struggle and fight against military rule across Africa such that military government is no longer fashionable in Africa, for it is one form of government that is notorious for the abuse of human rights.

However, under the "democratic" governments in Africa, human rights are still being seriously abused. The US Department of State in its annual country reports continues to show this. Amnesty International has continued to report abuse of human rights in the Buhari administration ranging from extrajudicial killings, unlawful incarceration and torture, oppression of the 
opposition groups, police and military brutality, oppression of the press, not holding state and individual agents of murder who use extreme and deadly force to account. It is not, therefore, enough to have the precepts of human rights enshrined in the Nigerian constitution whereas the government is doing nothing to put it into force. Herdsmen have persistently wasted human lives in Nigeria under the Buhari administration; human life is the primary and most fundamental of human rights, but the government has not done anything to stem the tide for whatever reasons including the religious and ethnic. This is ridiculous. For goodness sake our common humanity supersedes any other considerations. The Buhari administration has not also been popular with respecting the judgments of the courts; when several courts have for example, judged that El Zakzaky and Sambo Dasuki should be released, it beats ones imagination what those people are still doing in jail today. Their fundamental human rights to freedom of movement and of the person are being thus abused in a government that calls itself democratic.

\section{Conclusion}

Human rights consciousness has, as among other peoples, been native to the Africans and Nigerians. Only what was needed was the documentation. The colonial masters in a bid to maximize their gains in ruling the colonized peoples of Africa, including Nigeria, robbed us of some of our fundamental rights like rights to freedom of speech, of association or to govern ourselves, of movement in some countries, etc. But they had to relinquish power at some point but not without still having stooges and exercising overbearing power in Africa. The evolving African leaders under this influence turned out to be monsters to their own people. In Nigeria military governments, especially abused the human rights of the people; but 
also even the present "democratic" government has not fully started to execute the demands of the constitution in giving Nigerians a leadership that is people oriented and that respects the rights of the people. The government should therefore put the common humanity of all Nigerians in the forefront of every other consideration, and human rights will soon start being respected and then our country will make progress.

\section{Recommendations}

1. In all levels and types of education in Nigeria/Africa there should be provided in the civic education (or similar subject) curriculum a course for the inculcation into the minds of citizens the fundamental equality of all human beings and the duty to treat all with dignity, and that repudiation of this must be resisted by all with all available resources.

2. History as a subject must be brought back as a compulsory course in the Nigerian primary and secondary education system so as to provide avenues for citizens to learn through history the values of respect for human rights.

3. Nigerian politicians must be made to have political ideologies and such ideologies must take into consideration our Africanity and be based on service to the masses.

4. Tribalism and religious fanaticism should be treated as a crime, for through them government and non-government agents have discriminated against others and violated their human rights. We could copy the Rwandan now hugely successful model.

5. Fiscal restructuring of Nigeria into zones allowing for greater devolution of powers as canvassed by most Nigerian elites (at 
least in four of the six zones) today should be granted or wrestled from the government as it will enhance better respect of human rights in Nigeria.

\section{Paul Okwuchukwu Azuakor (PhD) \\ Department of Social Sciences, School of General Studies \\ Federal Polytechnic, Oko, Nigeria frpaulokwy4all@gmail.com}

\section{References}

Adebajo, K. (2018). Review: Three years of Buhari in office, and a poor human rights record. Retrieved October 10, 2019 from https://www.icirnigeria.org/review-three-years-of-buhariin-office-and-a-poor-human-rights-record/

Atupulazi, J. (2016). Murder of Bridget Agbaheme in Kano: Enough is enough. Fides editorial, (June 12-18).

Azuakor, P. O. \& Onebunne, J. I. (2016). Fulani herdsmen rampage in Nigeria: The philosophical, ethnic and religious undertones. International Journal of Social Science and Sustainable Development, 6(1), 95-101.

Babalola, I. (2019). NLTP: The human face of a savage scheme. Saharareporters online newspaper. Retrieved July 17, 2019 fromwww.ifedabs@ hotmail.com

Brisibe, P. (2018). Herdsmen attack, rape, chase Delta women from their farms. Niger Delta voice, in Vanguard, Tuesday, Nov. 6, Vol. 26, No. 63674.

Campbell, J. (2019). Amnesty sets agenda to address Nigeria's human rights violations. Africa in transition, Africa program, and Nigeria on the brink. Retrieved October 10, 
2019 from https://www.cfr.org/blog/amnesty-sets-agendaaddress-nigerias-human-rights-violations

Catholic Bishops' Conference of Nigeria (2010). Growing a new Nigeria. (Joint Pastoral Letter of Catholic Bishops' Conference of Nigeria on the $50^{\text {th }}$ Anniversary of Nigeria's Political Independence. Abuja: Catholic Secretariat of Nigeria).

Essien, A. (2016). Nigeria's human rights activities in history. Retrieved October 10, 2020 from https://allafrica.com/stories/201607010881.html

Federal Republic of Nigeria (1999). 1999 Constitution of the Federal Republic of Nigeria.

Federal Republic of Nigeria (2006). National action plan for the promotion and protection of human rights in Nigeria.

Fleshman, M. (2004). Human rights move up on Africa's agenda.

Retrieved October 10, 2019 from

https://www.un.org/africarenewal/magazine/july-

2004/human-rights-move-africas- agenda

Human Rights Watch (2019). Southern Africa: New leaders can do more for rights. World report 2019. Retrieved October 17, 2019 from https://www.hrw.org/news/2019/01/17/southernafrica-new-leaders-can-do-more-rights

Hussaini, J. \& Tsaku, H. U. (2016). Democracy and human rights in Nigeria: Proffering a TfD Approach. Retrieved October 10, 2019 from https://irepos.unijos.edu.ng/jspui/bitstream/123456789/186 4/1/DEMOCRACY\%20AND\%20HUMAN\%20RIGHT.pd $\mathrm{f}$

Ibekwe, N. (2019). How Buhari administration encourages human rights abuses-U.S. Government. Premium Times-Saturday, October 5, 2019. 
Igue, J. O. (2010). A new generation of leaders in Africa: What issues do they face? International Development Policy (Revue internationale de politique de développement), 1 , 115-133.

Jarrett, H. R. (1974). Africa: The new certificate geography series 'A' level, (4 ${ }^{\text {th }}$ edition). London: Macdonald \& Evans.

Kweifio-Okai, C. \& Holder, J. (2016). Democracy in African countries: Five myths explored. The Guardian.com, Thu 25 Feb 2016 07.12 EST

Magnarella, P. J. (2000). Achieving human rights in Africa: The challenge for the new millennium. African Studies

Quarterly, 4 (2), http://www.africa.ufl.edu/asq/v4/v4i2a2.pdf

Mbanefo, I.M.A. \& Ilogbunam, E.N. (2016). Citizenship education for Nigerian tertiary institutions. Onitsha: Varsity.

Mordi, R. (2019). Soyinka, Ooni to Nigerians: Defend your ancestral lands. The Nation, Mon, July 8, Vol. 13, No. 4724.

Obingene, A. U. \& Okeke, M. I. (2004). Citizenship education: Concepts and application (Vol. 2). Enugu: Zik-Chuks.

Ofoegbu, J.U. (2013). The place of human rights in Nigeria's democracy. Ogirisi: A new journal of African studies, 10. http://dx.doi.org/10.4314/og.v10i 1.4

Okechukwu, S. N. (1990). The right to life and the right to live: Ethics of international solidarity. Frankfurt: Peter Lang.

United States Department of State, Bureau of Democracy, Human Rights and Labor (2018). Nigeria 2018 human rights report (Country Reports on Human Rights Practices for 2018). Retrieved October 7, 2019 from https://www.state.gov/wpcontent/uploads/2019/03/Nigeria-2018.pdf

Wikipedia (2019). Federalism in Nigeria. Retrieved October, 9, 2019 from http://en.m.wikipedia.org. 